\title{
Perforation of left innominate vein during dialysis catheter placement
}

\author{
Saurav Gupta, Krishna Mohan Gummalla, Sundeep Jaywantraj Punamiya, Pua Uei
}

Department of Radiology, Tan Tock Seng Hospital, Singapore, Singapore

\section{Correspondence to} Dr Saurav Gupta, drsauravgupta@gmail.com

Accepted 28 September 2014

\section{DESCRIPTION}

A 67-year-old man presented with non-functioning left brachiocephalic arteriovenous fistula (AVF). The patient was referred for left internal jugular vein (IJV) dialysis catheter placement while awaiting right AVF creation. Ultrasound-guided left IJV puncture was successfully obtained, ${ }^{1}$ and a guide wire parked in the inferior vena cava through the access site. A $28 \mathrm{~cm}$ palindrome was placed, in what we thought was the superior vena cava, after tunnelling through the anterior chest wall. At the end of the procedure, no blood could be aspirated through either port of the palindrome. Contrast injected through the palindrome extravasated into the pleural cavity (figure 1). CT scan confirmed perforation of the mid innominate vein.

Venogram of the left innominate vein was obtained through an $8 \mathrm{Fr}$ sheath, placed in the left cephalic vein to ascertain the site of perforation. After securing the site with an $8 \times 4 \mathrm{~mm}$ balloon, the dialysis catheter was removed. A covered stent was then placed over the site of perforation through another $9 \mathrm{Fr}$ sheath placed in the left groin. Completion venogram showed no active extravasation of contrast (figure 2). Another palindrome was placed with smooth flow of blood through both the ports at the end of the procedure.

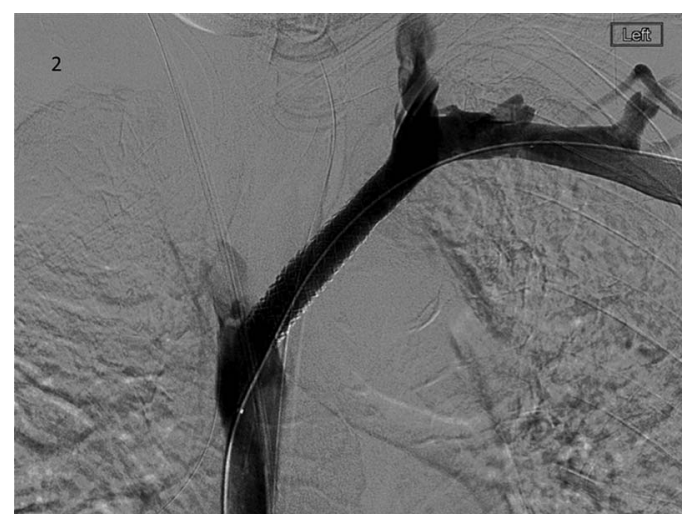

Figure 2 Venogram post-stenting showing satisfactory position of stent with no active extravasation of contrast.

After an uneventful $24 \mathrm{~h}$ of observation in the wards, dialysis was started through the catheter and carried on successfully until the AVF creation.

Apart from perforation, other complications encountered during dialysis catheter placement are arterial puncture, haematoma, pneumothorax, malposition, central venous stenosis, thrombosis, infection and phrenic nerve injury. ${ }^{2} 3$
To cite: Gupta $S$,

Gummalla KM, Punamiya SJ, et al. BMJ Case Rep Published online: [please include Day Month Year] doi:10.1136/bcr-2014206870

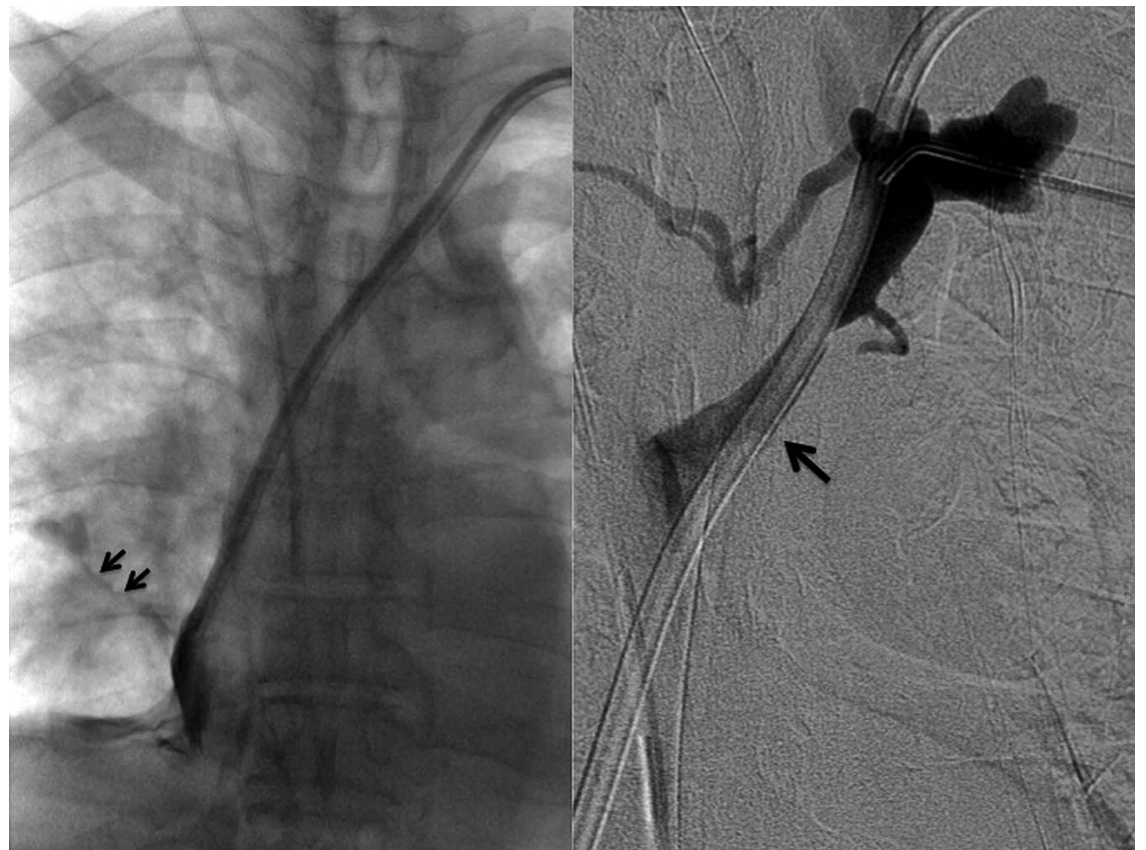

Figure 1 Initial injection of contrast through the perm catheter showing extravasation of contrast into the pleural cavity, arrows in (A). Venogram obtained from a catheter through the left arm sheath showing the permcath perforating through the mid innominate vein, arrow in (B). 


\section{Learning points}

- Ultrasound-guided venous access decreases the chance of arterial perforation during venous access.

- The route taken by the dialysis catheter is a potential indicator of malposition and perforation during dialysis catheter placement. However, the most important indicator is no flow of blood from the ports of the catheter.

- Haemorrhage in perforations at the level of the base of the neck can be controlled by manual compression. When deep down, balloon-assisted haemostasis and stenting are possible options.
Competing interests None.

Patient consent Obtained.

Provenance and peer review Not commissioned; externally peer reviewed.

\section{REFERENCES}

1 Bansal R, Agarwal SK, Tiwari SC, et al. "A prospective randomized study to compare ultrasound-guided with non-ultrasound guided double lumen internal jugular catheter insertion as a temporary hemodialysis access." Ren Fail 2005;27:561-4.

2 Tang MKH, Siu YP, Ng YY, et al. Misplacement of a right internal jugular vein haemodialysis catheter into the mediastinum. Hong Kong Med J 2004;10:135-8.

3 Mir S, Serdaroglu E. An elevated hemidiaphragm 3 months after internal jugular vein hemodialysis catheter placement. Semin Dial 2003;16:281-3.

Copyright 2014 BMJ Publishing Group. All rights reserved. For permission to reuse any of this content visit http://group.bmj.com/group/rights-licensing/permissions.

BMJ Case Report Fellows may re-use this article for personal use and teaching without any further permission.

Become a Fellow of BMJ Case Reports today and you can:

- Submit as many cases as you like

- Enjoy fast sympathetic peer review and rapid publication of accepted articles

- Access all the published articles

- Re-use any of the published material for personal use and teaching without further permission

For information on Institutional Fellowships contact consortiasales@bmjgroup.com

Visit casereports.bmj.com for more articles like this and to become a Fellow 